\title{
A Sombra das Vossas Asas o corpo como rascunho e projeto de si
}

Érica Schlude Wels ${ }^{1}$

\begin{abstract}
RESUMO: Arquiteturas corporais, consumo, alta e baixa cultura e processos de hibridização na hipermodernidade são os temas centrais do recorte teórico do presente artigo, a partir da crítica empreendida por autores como Baudrillard (2004, 2003, 1991), Lipovetsky (2004), Canclini $(2003,1999)$. Como obra-síntese dessas questões, escolhemos o romance "A sombra das vossas asas" (1997), de Fernanda Young, no qual o corpo da escritora ganha voz no plano narrativo; o enredo se constitui a partir de uma reconstrução corporal da protagonista, com vistas à aparência da modelo Lee Miller. Participam igualmente dessa leitura aspectos midiáticos, presentes também na figura da romancista, além da sedução, proporcionada por uma espécie de projeto pessoal de si mesmo, guiado pela moda e pelo consumo.
\end{abstract}

PALAVRAS-CHAVE: Corpo; Consumo; Hipermodernidade; Moda; Fernanda Young.

\begin{abstract}
Body architectures, consumerism, high and low culture and hybrid processes in the hipermodernity are the main themes on the theorical framework of the present article, having as basis the critical works of authors such as Baudrillard (2004, 2003, 1991), Lipovetsky (2004), Canclini $(2003,1999)$. As a synthesis of these themes, we have chosen the novel of Fernanda Young, "A sombra das vossas asas", in which the body of the writer has its own voice in the narrative; the plot is developed from the body reconstruction of the main character, who has as the goal of copying the appearance of the model Lee Miller. Midiatic aspects, which are present in the figure of the novelist, also takes part in this reading, besides the seduction, obtained through a type of a self personal project, guided by fashion and consumerism.
\end{abstract}

KEYWORDS: Body, Consumerism, Hypermodernity, Fashion, Fernanda Young.

Não sou este agregado de membros que é chamado de corpo humano.

René Descartes

A imagem da escritora, atriz e roteirista carioca Fernanda Young - suas tatuagens e visual gótico-, fez com que se tornasse conhecida dos brasileiros a partir de sua exibição na mídia, seja como entrevistadora, seja na pele de uma de suas personagens, na série humorística "Surtadas na Yoga" (2013-2014), ambos exibidos recentemente pelo canal televisivo GNT. Contudo, Young já publicou um total de 11 obras, na sua maioria romances, além de poemas, tendo estreado em 1996, com o livro "Vergonha dos pés". Como roteirista, Fernanda Young possui uma carreira de sucessos, em diversos trabalhos para o cinema e TV, como "A comédia da vida privada" (1995), "Os Normais" (2001-2003) e "Minha nada mole vida" (2006), somente para citar os títulos mais conhecidos. Sua participação na TV engloba ainda o trabalho como apresentadora, em programas estilo "Talk-show", como "Saia Justa"

Professora de língua alemã do Departamento de Letras Anglo-Germânicas da Faculdade de Letras da Universidade Federal do Rio de Janeiro. Email: <schludew@gmail.com>. 
(2002-2003) e "Irritando Fernanda Young" (2006-2010), ambos transmitidos pelo GNT. Desde novembro de 2015, a escritora volta ao formato humorístico televisivo, assinando, ao lado do marido e roteirista Alexandre Machado, os episódios da série "Odeio Segundas", exibidos pelo Canal GNT, e tendo a atriz Marisa Orth à frente do elenco.

Pretende-se no presente artigo relacionar aspectos teóricos ligados ao corpo e ao consumo na contemporaneidade, a fim de pensar como esses elementos, ligados à moda, ao visual, à construção de uma identidade e de uma imagem sedutora, reverberam na busca pela aceitação do Outro e pelo amor, tendo como base o romance "A sombra das vossas asas" (1997), de Fernanda Young. Nele, a protagonista Carina é o rascunho do projeto de si, recriando-se à imagem da beleza midiática, a partir de cirurgias plásticas transformadoras e de um visual cuidadosamente planejado. A trajetória de Young também nos oferece pontos de reflexão, já que gera, com sua exposição na mídia, o consumo de sua imagem. No jogo ficcional, seu corpo e sua voz invadem a trama do romance.

\section{A sombra das vossas asas: o projeto de si}

A escrita produzida por Fernanda Young situa-se dentro do rótulo de "midiática"; abarcando a utilização de uma linguagem afetiva, em franco diálogo com o leitor, construindo enredos e tecendo um poderoso e envolvente imaginário. Ademais, percebe-se a utilização de tipos e de enredos que geram identificação junto ao público. No plano da linguagem, é marcante a influência da velocidade e dos apelos da escrita para TV e para o cinema, o que se liga ao trabalho da escritora como roteirista.

O corpo é o locus privilegiado do segundo romance de Young. Em "A Sombra das Vossas Asas" (1997), é o corpo que se pronuncia, logo no início da narrativa, quando ganha voz a narradora-escritora:

Eu era capaz de concluir sobre uma vida inteira, só precisava olhar a nuca do indivíduo. Foi quando determinei que existem apenas três defeitos físicos decididamente irremediáveis: não ter cintura, ter tornozelos grossos e braços curtos. (YOUNG, 1997, p. 8)

As reflexões sobre defeitos físicos são substituídas pelo pensamento a respeito do ofício do escritor, que também utiliza o corpo para registrar fielmente as impressões que capta da realidade:

Fico pensando se faltasse em minha vida a literatura. Imagino como eu estaria. Dizem que, durante o sono, a mente seleciona aquilo que é importante registrar do que irá para o lixo. Devo sofrer algum tipo de insuficiência seletiva, uma vez que a minha cabeça está sempre transbordando inutilidades. Escrevo romances por isso, para esvaziar o cérebro, para xeretar a vida dos outros sem atormentar ninguém. (YOUNG, 1997, p. 8) 
Ainda nas páginas iniciais de "A sombra das vossas asas", a narradora-escritora reflete sobre si mesma, explora suas reminiscências, trazendo novamente o corpo e suas vestes para o centro da discussão:

As vestes que cobrem os nossos corpos são feitas de hipocrisia, mentira, ignorância. E eu somente quero - sempre quis - despir-me de tudo. A lã pinica o meu corpo. A lã me dá alergia. Eu tenho nojo. A lã me deixa nervosa. E eu somente quero deitar em paz e acordar com paz. Somente isso: paz de espírito. (YOUNG, 1997, p. 29)

No enredo do romance, a exemplo dos corpos dos protagonistas, que se encontram para não mais se perderem, o corpo da narradora-escritora se distingue dos demais; um corpo que, segundo suas palavras, é constantemente salvo pelo ofício literário. Na esfera da vida pública, nas fotos e depoimentos da escritora, observa-se o uso de uma imagem moderna, humorística, mordaz, e em sintonia com os tempos atuais. Nesse caso, pode-se dizer que o corpo da escritora é usado na construção de uma imagem. Esta é, sem dúvida, uma imagem midiática, que pode ser sintetizada por inúmeros adjetivos: punk, tatuada, esquisita, rebelde, transgressora.

"A sombra das vossas asas" pode ser definido como um romance de corpos que se atraem, os de Rigel e Carina. Na obra "Fragmentos de um discurso amoroso", de Roland Barthes, encontramos a fórmula da especificidade do desejo. Ou seja, o teórico francês situa a paixão como um encontro único de corpos:

Encontro pela vida milhões de corpos; desses milhões, posso desejar centenas; mas dessas centenas, amo apenas um. O outro pelo qual estou apaixonado me designa a especialidade do meu desejo. [...]. Foram precisos muitos acasos, muitas coincidências surpreendentes (e talvez muitas procuras), para que eu encontrasse a Imagem que, entre mil, convém ao meu desejo. (BARTHES, 1990, p. 14)

No romance em questão, o fotógrafo Rigel, sedutor, encontra o amor da sua vida na determinada Carina. O texto começa justamente refletindo sobre o amor como esse encontro de corpos: "É possível que ele tenha cruzado várias vezes com aquela que deveria ser, ou será o amor de sua vida" (YOUNG, 1997, p. 13). A paixão, para o fotógrafo, era encontrada na mulher mais próxima; com Carina, no entanto, Rigel volta a experimentar o desejo de posse e a profunda identificação com o objeto amado, seguida do aniquilamento de si mesmo e do mergulho no amado.

Também em momentos reflexivos, o corpo toma o centro da narrativa, comparado a uma máquina, ainda que dotada de um mecanismo mais sofisticado: "O ser humano tem reações esquisitas, que no fim denunciam as fragilidades da raça. Coisa natural. É como um carro de corrida, uma máquina potente, avançada, mas que volta e meia pifa". (YOUNG, 1997, p. 42)

A narrativa também é costurada por signos da mídia. $\bigcirc$ texto fala de nomes artísticos e transita com desenvoltura entre Cindy Crawford, Revista Playboy, televisão. É o exemplo adequado para a cultura de consumo, um painel exuberante de ofertas e solicitações.

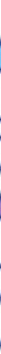


Escrita e corporalidade guiam a leitura do romance, mostrando ao leitor o que chamamos de dilemas corporais: a criação do corpo idealizado, que visa à perfeição e ao consumo, a paixão como um encontro de corpos; na personagem Carina, é o corpo o protagonista dessa paixão, ele mesmo em reconstrução.

A narrativa sobre Carina se inicia no ponto em que ela tem 19 anos e é uma jovem judia roliça e desajeitada, mas que aspira ao título de Miss Brasil. Todo o conflito psicológico vivido pela jovem baseia-se justamente numa autoimagem equivocada, num corpo que não corresponde a uma alma que aspira à perfeição.

Em Carina, há um forte sentido de ordem, de expurgar o que é imperfeito e inútil, primando pela beleza e pela mudança radical²: o pai doente, que exige cuidados constantes, o asco pela decrepitude, o isolamento de Rigel, da filha e da ex-mulher, ambas "feias e sem graça". Tudo o que se situa na esfera do humano deve ser (até ser, de fato) eliminado ou transformado numa versão aprimorada, logo, simulacro.

David Le Breton traça um mapeamento de trajetórias e arquiteturas corporais contemporâneas, o que pode sintetizar o "dilema" Carina, anteriormente exposto:

O corpo tornou-se a prótese de um eu eternamente em busca de uma encarnação provisória para garantir um vestígio significativo de si. [...] O corpo torna-se um emblema do self. A interioridade do sujeito é um constante esforço de exterioridade, reduzse à superfície. É preciso se colocar for a de si para se tornar si mesmo. (LE BRETON, 2003, p. 29)

Na visão de Le Breton, ao dispensar um antigo corpo incompreendido e mal-amado, a pessoa goza, por antecipação, de algo superior a uma nova identidade: um novo nascimento (2003, p. 30). É do autor a categoria de corpo-rascunho, destinado a remodelar-se em busca de aprimoramento.

Para Henri-Pierre Jeudy, há de se considerar o efeito estético das imagens do corpo: a não-satisfação do desejo existe na medida do poder metamórfico das imagens corporais, "[...] a transformação do corpo como objeto de arte seria uma satisfação que corresponde à insatisfação, graças ao prazer ocasionado pelo estado de não realização do desejo" (2002, p. 27).

Em acréscimo, a certeza da decomposição como destino de todo corpo explica a fascinação pela beleza presente. "O que designamos comumente como cirurgia estética não é senão um meio de descobrir seu "Outro"? Ou a preocupação maior é tornar-se radicalmente outro" (JEUDY, 2002, p. 121)

O ideal de Carina preenche-se de um modelo escolhido (Lee Miller) ao folhear uma revista com fotos de belas modelos dos anos trinta. É um jogo de espelhos, o interno que reflete o externo, sendo frágil e construído, e do externo que passa a refletir um ideal interno, porém, baseado numa aparência da mídia.

Na visão platônica, o corpo é o verdadeiro túmulo da alma, imperfeição, cópia toscamente concebida de uma humanidade, cujas raízes estão no céu, no mundo das ideias. 
Queria ser Lee Miller. E nunca mais um fotografozinho idiota iria maltratar seus sonhos. Nunca mais ninguém iria maltratar seus sonhos. Inclusive o fotografozinho idiota iria cair aos seus pés. Choraria pelo seu amor. Desejaria ter filhos com ela. Carina arrancou cuidadosamente as cinco páginas [...] Quando voltou para casa, trazia um envelope com 50 cópias xerox. Dez de cada foto. Cinquenta vezes Lee Miller. Que foram espalhadas estrategicamente pelas paredes. Carina fez das cópias seus novos espelhos. [...] Pois aquela que acharia não seria ela. Ela era Lee Miller. E, com o tempo, não apenas ela se veria tal qual a outra, mas todo mundo. (YOUNG, 1997, p. 56)

Além da transformação física, o projeto de Carina envolve a criação de um verdadeiro ideal de aparência, cuidadosamente planejado. Veste-se com esmero, de forma sedutora, com vestidos diáfanos e comprados em brechós. Orna o corpo com joias que aumentam a composição dramática de sua figura sedutora, sendo frequente o uso de inúmeras pulseiras de baquelite nos braços. Esse material é uma resina sintética, cujo nome é uma homenagem ao seu inventor, o químico belga L. H. Baekeland. Tais peças despertam o interesse de muitos colecionadores, em todas as formas, que vão além das joias, passando por botões, luminárias e outros itens. Entre os colecionadores famosos, encontra-se a própria escritora Fernanda Young, que possui uma das maiores coleções do Brasil de pulseiras de baquelite, das décadas de 20, 30, 40 e 50. Nesse aspecto, escritora e personagem compartilham a mesma preferência, ligada à construção de uma imagem.

A relação de Carina com seu corpo é um conflito permanente, pois se trata de um corpo que não é seu, mas que é eternamente o reflexo de um ideal. Tal relação encaixa-se na tipologia criada por Arthur Frank, no artigo "For a sociology of the body: an analytical review" (1996). Segundo as ideias do teórico, o corpo pode ser disciplinado, dominado, refletido ou comunicativo, categorias que variam segundo as dimensões do controle, desejo, relacionamento com os outros e autorrelacionamento. O corpo refletido é um corpo voltado ao consumo.

É também um corpo previsível e bem-sucedido, através da prática de seu regime. Baseado no consumo, torna-se tão óbvio quanto os objetos adquiridos por ele. $\bigcirc$ corpo refletido é aberto ao mundo externo e apropria-se deste através da aquisição de bens. Alcança seus objetivos em seu autorreflexo. Ele é associado, em sua própria superfície, ao mito de Narciso. Além das fotos da modelo Lee Miller transformadas em espelho, o amado de Carina, Rigel, é um fotógrafo, artista do olhar, esteta, capaz de operar transformações na realidade com o uso da câmera. Há uma espécie de hipertrofia da imagem e do olhar, nessa relação amorosa, unindo o casal num enlace obsessivo.

A imagem sorridente e perfeita de Lee Miller é a motivação da metamorfose carineana; no belo ensaio de Roland Barthes, intitulado "A câmara clara", encontramos reflexões sobre o imaginário fotográfico. Segundo Barthes, é possível falar de uma foto, mas não de fotografia, encontrando-se o teórico na tentativa de fazer uma "História dos olhares": "[...] Pois a fotografia é o advento de mim mesmo como outro: uma dissociação astuciosa da consciência da identidade. Ainda mais curioso: foi antes da Fotografia que os homens mais falaram da visão do duplo". (BARTHES, 1984, p. 25) 
A modelo posada detém Carina. A pose que dura um milionésimo de segundo traduz, em sua estudada imobilidade, os mais perversos desejos da personagem: anular-se, ser uma outra, personalidade fragmentada em personagem inventada. Sobre o impacto da pose, Roland Barthes explica:

[...] [a pose] é o termo de uma "intenção" de leitura: ao olhar uma foto, incluo fatalmente em meu olhar o pensamento desse instante, por mais breve que seja, no qual uma coisa real se encontrou imóvel diante do olho. [...] na foto, alguma coisa se pôs diante do pequeno orifício e aí permaneceu para sempre (está aí meu sentimento) (1984, p. 121);

Em seu estilo poético, Barthes resume o processo de sedução pela foto:

De um corpo real, que estava lá, partiram radiações que vêm me atingir, a mim, que estou aqui; pouco importa a duração da transmissão; a foto do ser desaparecido vem me tocar como os raios retardados de uma estrela. Uma espécie de vínculo umbilical liga a meu olhar o corpo da coisa fotografada: a luz, embora impalpável, é aqui um meio carnal, uma pele que partilho com aquele ou aquela que foi fotografado. (1984, p. 117)

O espelhamento de Carina na exuberante mulher toma como padrão o mito da beleza eterna e absoluta. Nas páginas finais de "A câmara clara", encontramos um breve comentário sobre o consumo de imagens na sociedade contemporânea:

[...] ○ gozo passa pela imagem: es aí a grande mutação. Uma tal inversão coloca forçosamente a questão ética: não que a imagem seja imoral, irreligiosa ou diabólica (como alguns declararam quando do advento da fotografia), mas porque, generalizada, ela desrealiza completamente o mundo humano dos conflitos e dos desejos, sob o pretexto de ilustrá-lo. (BARTHES, 1984, p. 174)

$\mathrm{Na}$ imagem idealizada, Carina encontra o seu ego, sua face perdida, num interessante jogo de inversão. A imagem dita o físico, em vez de o físico comandar a imagem: "O que caracteriza as sociedades ditas avançadas é que hoje essas sociedades consomem imagens e não crenças, como as do passado". (BARTHES, 1984, p. 174)

Ainda na categoria de Arthur Frank, de corpo disciplinado, encontramos o vínculo deste com o corpo refletido, uma vez que é igualmente previsível. Na busca pelo reflexo ideal, o corpo refletido nutre uma disciplina monástica. No romance, são muitas as privações e sofrimentos pelos quais passa Carina, a fim de empreender sua metamorfose. Em outras palavras, a transformação da gordinha Carina na exuberante Lee Miller só é possível através dos processos de desmaterialização e metamorfose, propiciados pela técnica, desconstruindo o que antes parecia irrevogável.

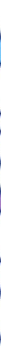


Antes da metamorfose, Carina demostra desprezo pelo próprio corpo. Nesse período, a relação com o corpo do outro é de igual repulsa, como atesta a perda da virgindade de forma mecânica, numa sedução ensaiada, e não por acaso, destinada ao cirurgião plástico. Os beijos da adolescência remetem à náusea e ao mal-estar pelas lembranças dos anos de isolamento e bullying na escola.

Mesmo após tantas transformações, o corpo de Carina é o cárcere da menina gordinha, que outrora fora desprezada pelo fotógrafo atraente. A metamorfose é pura ficção. A memória daquele corpo que ela tanto desprezava permanece intacta, num canto escuro de sua consciência e, nos momentos de insegurança, é essa Carina dividida entre corpo modificado e corpo natural, que vem à tona:

Não há plástica que modifique sua memória - é bem mais fácil encomendar um novo nariz. Não há lipo que livre suas ideias dos excessos de recordação. Então não houve jeito de apagar da cabeça o desprezo que Rigel havia sentido por ela. Mesmo o amor que ele dedicou a ela não foi capaz de abafar aquela dor que havia sentido anteriormente [...]. (YOUNG, 1997, p. 99)

Na trama de "A sombra das vossas asas" o casal enfrenta crises, geralmente motivadas pelo ciúme de Carina. Ela continua a enxergar nas outras mulheres rivais poderosas, rebaixando-se como feia e gorda, ou seja, permanecendo unida à imagem real de seu corpo antes das cirurgias. Contudo, a loucura da esposa termina por fascinar o fotógrafo, deixando-se fisgar e aceitando o pacto que Carina lhe propõe. Assim, o amor obsessivo torna-se o laço que os une.

\section{Arquiteturas corporais: aspectos teóricos}

Um corpo que se transforma cada vez mais em corpo-máquina, "corpo-bricolagem, resultado de excessos e derivas" (LE BRETON, 2003, p. 9). É um corpo imperfeito, lido como rascunho a ser corrigido. $O$ sucesso das cirurgias estéticas é revelador: muda-se o corpo, na tentativa de se mudar a vida. Além disso, o corpo é simulacro; é descartável e fragmento: boca, seios, olhos, pernas, não há unidade, conjunto orgânico. $\bigcirc$ sujeito almeja construir a melhor versão de si mesmo. "O corpo exaltado não é o corpo com o qual vivemos, mas um corpo retificado, redefinido". (LE BRETON, 2003, p. 10)

No livro "O corpo como objeto de arte", Henri-Pierre Jeudy flagra um corpo em metamorfose estética cotidiana, a qual se aproximaria da criação artística. Cada dia seria, dessa maneira, uma encenação nessa "teatralização da vida", guiada por uma "obstinação estética" (2002, p. 17). Uma das ideias centrais desse autor é que o corpo é agente de constantes desfigurações, guiadas pelo fascínio por imagens, contra as quais, no entanto, não cessamos de lutar, crendo fabricar representações únicas e originais.

Como invólucro do corpo que busca, a todo custo, se embelezar, está o desejo de seduzir. Se meu corpo é objeto para o Outro, ele é, primeiramente, o meu objeto. O exercício 
contínuo da sedução objetiliza radicalmente o corpo, e cada vez que surgem fraquezas ou sinais de decomposição, o sujeito experimenta a angústia da decadência, e a possibilidade da morte.

Para Jeudy, trata-se de uma verdadeira sacralização do corpo, o qual ganha o suporte da universalidade do Belo. "A admiração é o meio moral e estético de sublimar o desejo" (p. 23). Além disso, a estetização não é outra coisa senão o meio ilusório de impor alguma ordem ao corpo.

Jair Ferreira dos Santos, em "Breve, o pós-humano", apresenta ensaios que comprovam o afastamento de um modelo natural, em direção à uma estética e moral hedonistas e efêmeras:

Há muito tempo "nosso" corpo não é mais nosso. Ele pertence antes a discursos sobre saberes e tecnologias que o reconcebem conforme os avanços científicos, mas também é reinventado, periodicamente, pelas veleidades mercadológicas da moda, da ginástica, do esporte, da cirurgia plástica. A impressão é de que só podemos vê-lo com os olhos desses "outros", num morfismo sem fim de alegres prisioneiros do estágio espetacular. Nesse aspecto, nenhum vetor revela maior influência que a indústria da beleza (e suas relações particulares com a feiura). (SANTOS, 2002, p. 99)

Muitas são as vozes teóricas que complementam tal visão, em sintonia com as reflexões que apresentamos, a partir da construção imagética em Fernanda Young e seu romance. Destacamos, desse corpo teórico, Gilles Lipovetsky, com seus "Tempos Hipermodernos":

[...] Nasce uma cultura hedonista e psicologista que incita à satisfação imediata das necessidades, estimula a urgência dos prazeres, enaltece o florescimento pessoal, coloca no pedestal o paraíso do bem-estar, do conforto e do lazer. Consumir sem esperar; viajar; divertir-se; não renunciar a nada: as políticas do futuro radiante foram sucedidas pelo consumo como promessa de um futuro eufórico. (LIPOVETSKY, 2004, p. 61)

A visão de Le Breton é a renúncia à dicotomia matéria-essência, situando a atualidade num eclipse do espírito e prendendo o homem, cada vez mais, ao corpo ${ }^{3}$. Paradoxalmente, ligando-o ao que não é mais definitivo, o corpo é rapidamente consumido, apresentando-se como manipulável e transitório. Contudo, para esse autor, alma e corpo estão tanto simultaneamente ausentes, quanto presentes: " [...] O corpo é normalmente colocado como um alter ego consagrado ao rancor dos cientistas. Subtraído do homem que encarna à maneira de um objeto, esvaziado de seu caráter simbólico, o corpo também é esvaziado de qualquer valor". (LE BRETON, 2003, p. 15)

Ao mesmo tempo que o corpo é cercado de cuidados e práticas que o disciplinam e moldam, o estresse e a obesidade ganham espaço na vida moderna, reduzindo a escoIha do sujeito contemporâneo, constantemente estimulado. Junto a isso, os sentidos se

Uma tendência de autores contemporâneos, ao se debruçarem sobre a questão do corpo, é revisitar os clássicos filosóficos, iniciando por Platão, avançando até Descartes e complementando o diálogo com Nietzsche, Espinosa e Deleuze. Em diversas leituras, esses filósofos são citados como predecessores sobre as questões acerca da dicotomia corpo-alma.

A Sombra das Vossas Asas: o corpo como rascunho e projeto de s 
embotam e surge uma espécie de atrofia. Os corpos se movem por entre escadas e esteiras rolantes e recebem aparatos que roçam o físico e o sensorial, instituindo uma espécie de barreira higienizante, a favor da ordem e da padronização, iludindo a todos na direção do controle do caos. Presente, o corpo está ausente do mundo, e passa a ser visto em fragmentos. A expressão de Sigmund Freud, o homem enquanto "deus de prótese", presente no "Mal-estar na civilização", é, mais do que nunca, atual.

Estruturando o binarismo corpo-discurso, Jean Baudrillard desloca a sedução para a ordem do segredo, em oposição à produção, da esfera do visível, no qual a sedução atua. $\bigcirc$ campo da produção é erigido na evidência de seus objetos. A banalização do imperativo sexual (não o sexo em si) é o responsável pelo esvaziamento do processo ritualístico da sedução. Este se apaga por trás da realização imediata dos desejos. A sedução desloca o sentido dos discursos, desvia a verdade.

Seduzir é morrer como realidade e produzir-se como engano. É ser presa de seu próprio engano e mover-se num mundo encantado. Esse é o poder da mulher sedutora, presa de seu próprio desejo, que encanta a si mesma de ser engano no qual os outros, por sua vez, virão se prender. (BAUDRILLARD, 1991, p. 80)

\section{Baixa cultura versus alta cultura. Globalização versus hibridização.}

Autora de obras voltadas ao consumo, produzindo literatura de entretenimento, Fernanda Young nos leva a questionar a presença desse gênero em trabalhos acadêmicos. $\bigcirc$ contexto brasileiro é ainda mais desafiador, uma vez que falamos da ausência de um público leitor expressivo, em comparação com outros países, onde se discute a presença da literatura de massa. Devido a esses aspectos, elegemos como possíveis guias as leituras de Néstor García Canclini.

Tendo como base paradigmas de produção cultural, Canclini aborda a multiculturalidade como ponto de partida de seu pensamento, uma vez que considera a globalização não um processo de homogeneização, mas sim, de "reordenamento das diferenças e desigualdades". (1999, p. 11). O termo "globalização" ganha, assim, status de interação funcional de atividades econômicas e culturais dispersas, bens e serviços gerados por um sistema de muitos centros, cujo funcionamento depende da velocidade e das posições geográficas a partir das quais se age. Vejamos a opinião do autor: "[...] as manifestações culturais foram submetidas aos valores que 'dinamizam' o mercado e a moda: consumo incessantemente renovado, surpresa e divertimento". (1999, p. 42)

Como intelectual nascido na Argentina, seu olhar se dirige para as cidades e indústrias culturais da América Latina, locus periférico e dependente "dentro de um sistema mundial de intercâmbios desiguais disseminados" (p. 13). Em "Consumidores e Cidadãos", é o consumo o símbolo do funcionamento local, "espaço da racionalidade econômica, sociopolítica e psicológica das sociedades" (p. 15). Sob o prisma do consumo e seus significados, podemos

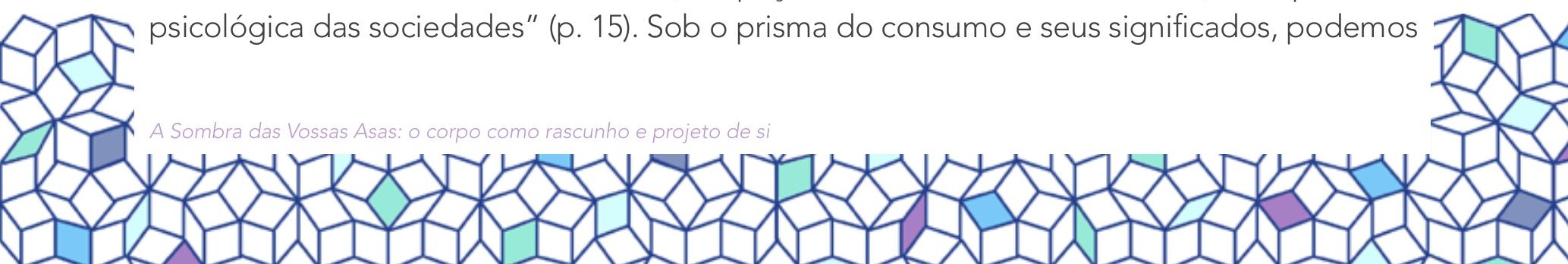


entender o quanto identidades eram essências ahistóricas, passando a configurar-se, atualmente, no consumo: para as gerações, a construção da diferença dá-se através daquilo que se possui, ou daquilo que se pode chegar a possuir. $\bigcirc$ consumo pressupõe uma seleção de bens que une o pragmático ao aprazível (1999, p. 45). Dessa forma, a tese principal de Canclini é de que assistimos a uma profunda reorganização social, remetendo-nos a consumidores do século XXI e cidadãos perdidos nas utopias de um distante século XVIII. A insistência de Canclini é na representação simbólica dos bens adquiridos, tendo repercussões no espaço ocupado pelo corpo, espaço da transitoriedade e da performance, por excelência.

[...] comprar objetos, pendurá-los ou distribuí-los pela casa, assinalar-lhes um lugar em uma ordem, atribuir-lhes funções na comunicação com os outros, são os recursos para se pensar o próprio corpo, a instável ordem social e as interações incertas com os demais. Consumir é tornar mais inteligível um mundo onde o sólido se evapora. (CANCLINI, 1999, p. 83)

"Culturas híbridas", também de Néstor García Canclini, examina os processos de hibridização, na esteira do pensamento crítico sobre a multiculturalidade ou interculturalidade. Por hibridização, Canclini nomeia não só as combinações de elementos étnicos ou religiosos, mas também a de produtos das tecnologias avançadas e processos sociais. Tal processo situa-se na contradição entre as fronteiras de grandes cidades, formatos e estilos:

[...]Mas essa multiplicação de oportunidades para hibridar-se não implica indeterminação, nem liberdade irrestrita. A hibridação ocorre em condições históricas e sociais específicas, em meio a um sistema de produção e consumo que às vezes operam como coações [...] (2003, p. XXIV)

Interessam-nos, principalmente, as afirmações de que as antigas oposições entre tradicional e moderno, culto e popular, "não estão onde estamos habituados a encontrá-las" (p. 24). Para o teórico, faz-se necessário demolir a divisão entre os pavimentos do que é culto, popular e massivo, a fim de se averiguar sua hibridação. Por isso, "[...] Precisamos de ciências sociais nômades, capazes de circular pelas escadas que ligam esses pavimentos. Ou melhor: que redesenhem esses planos e comuniquem os níveis horizontalmente". (2003, p. 19)

No lugar do termo "Globalização", o conceito "Hipermodernidade", de Gilles Lipovetsky, insere reflexões sobre a contemporaneidade, do ponto de vista de categorias marginalizadas pelos estudos filosóficos, como o consumo e a moda. Nos "tempos hipermodernos", o filósofo traça a "terceira revolução moderna", isto é, um "aprofundamento humanista do individualismo" (2004, p. 8). Estaríamos vivendo a era do vazio, mas sem tragédia nem apocalipse, na qual valem mais estratégias de sedução do que noções de alienação ou disciplina.

A "terceira modernidade" é a era do hiperconsumo, do hipernarcisismo, de contradições marcantes: quanto mais avançam as condutas responsáveis, mais aumenta a irresponsabilidade. Indivíduos hipermodernos mais informados, ao mesmo tempo que mais

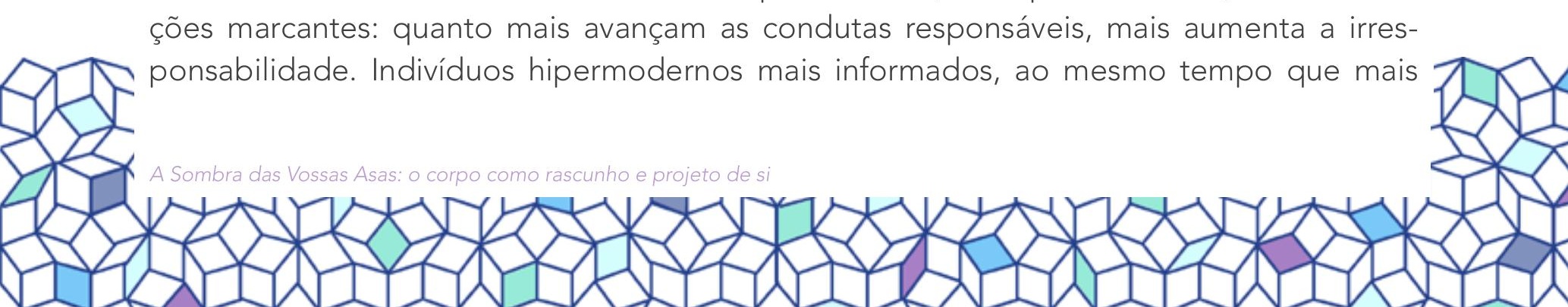


desestruturados, mais instáveis, mais ideológicos e mais tributários nas modas, mais abertos e mais influenciáveis, mais críticos e mais superficiais, mais céticos e menos profundos. O relativismo também é uma faceta da Hipermodernidade.

O motor de nossa era é, portanto, o da contradição: ao lado das promessas do progresso científico, permanecem a sensação de fuga da realidade e a mercantilização. A ênfase é no movimento, na hipermudança livre do peso da utopia, sob o imperativo da eficiência. Somado a isso, o princípio da moda amplia sua influência, ou seja, alimenta a atração desmedida pelo novo. O presente configura-se incerto, e talvez por isso mesmo, mais o indivíduo se apega a ele, diante da frouxidão do passado e do distanciamento do futuro:

[...] eis agora o tempo do desencanto com a própria pós-modernidade, da desmitificação da vida no presente, confrontada que está com a escalada das inseguranças. O alívio é substituído pelo fardo, o hedonismo recua ante os temores, as sujeições do presente se mostram mais fortes que a abertura de possibilidades acarretadas pela individualização da sociedade. De um lado, a sociedade-moda não para de instigar aos gozos já reduzidos do consumo, do lazer e do bem-estar. De outro, a vida fica menos frívola, mais interessante, mais apreensiva. (LIPOVETSKY, 2004, p. 65)

Além de dirigir suas críticas ao termo "pós-moderno", Lipovetsky discorda do presente eterno ou autossuficiente. Ele acredita muito mais em tensões paradoxais entre passado e futuro. Destaca-se ainda a decadência do culto mecânico ao progresso, no lugar de um futuro puro, a ser construído sem garantias, sem caminhos pré-traçados, sem leis implacáveis, em aberto.

Outro tema presente nas reflexões acerca da contemporaneidade, a problemática consumista, é abordada por Jean Baudrillard, nas obras "A sociedade de consumo" e "O sistema dos objetos". Dentre os vários conceitos defendidos por Baudrillard no primeiro livro mencionado, o de "commodity sign" resume a visão do consumo além da abundância, do descarte de mercadorias, da moda, da presença da sociedade de Mercado: liga-se ao consumo do signo. Na segunda parte de seu livro, intitulada "Teoria do Consumo", Baudrillard une a ideia da necessidade ao direito natural pelo gozo e pela felicidade:

[...] Inscrita em caracteres de fogo por detrás da menor publicidade para as Canárias ou para os sais de banho, a felicidade constitui a referência absoluta da sociedade de consumo, revelando-se como o equivalente autêntico da salvação. (BAUDRILLARD, 2003, p. 47)

Subjacente ao mito da felicidade, encontra-se o direito pela igualdade, sustentado pela crença na mensurabilidade da felicidade, isto é, um bem-estar traduzido por objetos e signos de conforto. Trata-se da "reabsorção das fatalidades sociais e igualização de todos os destinos" (BAUDRILLARD, 2003, p. 47), porém, levados a propósito de critérios visíveis, fundamentados nos princípios individualistas: 
[...] todos os homens são iguais, porque todos eles são iguais diante do valor de uso dos objetos e dos bens (se bem que sejam desiguais e se encontrem divididos em relação ao valor de troca). Porque a necessidade se cataloga pelo valor de uso, obtém-se uma relação de utilidade objetiva ou de finalidade natural, em cuja presença deixa de haver desigualdade social ou histórica. Ao nível de bife (valor de uso), não existe proletário nem privilegiado. (BAUDRILLARD, 2003, p. 48)

O homo oeconomicus, que Baudrillard renomeia como homo psychooeconomicus, é dotado do princípio da racionalidade que o impele em duas direções: a busca, sem qualquer hesitação, da própria felicidade; a preferência pelos objetos que lhe trarão o máximo de satisfações. Sob a tautologia do "compro isso porque preciso", assistimos a uma conversão histérica ou psicossomática, com o sintoma, tal como o signo, tornado arbitrário. Engana-se ao identificar-se a necessidade com o objeto que ela procura, assim como o terapeuta se equivoca ao reduzir o tratamento tradicional ao órgão onde se localiza o sintoma. O mundo dos objetos seria, dessa forma, o mundo de "histeria generalizada". (BAUDRILLARD, 2004, p. 77)

Dentro dessa perspectiva, o corpo é instituído como o mais belo objeto de consumo. É necessário, através do consumo, que as pessoas se convençam de seu próprio corpo e que o ornem como capital e como feitiço, em permanente investimento e cuidado:

[...] A sua 'redescoberta' [a do corpo], após uma era milenária de puritanismo, sob o signo da libertação física e sexual, a sua onipresença (em especial, do corpo feminino) na publicidade, na moda e na cultura das massas - o culto higiênico, dietético e terapêutico com que se rodeia, a obsessão pela juventude, elegância, virilidade / feminilidade, cuidados, regimes, práticas sacrificiais que com ele se conectam, o Mito do Prazer que o circunda - tudo hoje testemunha que o corpo se tornou objeto de salvação. Substitui literalmente a alma, nessa função moral e ideológica. (BAUDRILLARD, 2004, p. 136)

\section{Conclusões}

Carina é, então, o ser fraturado, o rascunho de si mesma que busca no amor possibilidade de salvação. No romance analisado, a moda, o corpo e a paixão formam uma tríade que resume o dilema da protagonista e sua busca pelo objeto amado e pela aceitação do Outro.

Sendo a ficção de Fernanda Young marcada por diversos signos da hipermodernidade consumo, sexo, meio urbano, metamorfoses corporais etc. - e seu texto influenciado pela rapidez e dinamismo da escrita midiática, podemos apontar para um jogo de espelhos entre obra, sociedade e imagem. Essa imagem traz, no romance em questão, o próprio corpo para o plano narrativo. Jogos ficcionais, trapaças romanescas à parte, oscila-se entre salvação (pela escrita, pelo Outro, pelo Amor) e imagem (mídia, moda, sedução). 


\section{Referências}

BARTHES, Roland. Fragmentos de um discurso amoroso. 10 ed. Rio de Janeiro: F. Alves, 1990. A câmara clara. Nota sobre a fotografia. Trad. de Júlio Castaňon Guimarães. Rio de Janeiro: Nova Fronteira, 1984. BAUDRILLARD, Jean. O sistema dos objetos. Trad. de Zulmira Ribeiro Tavares. São Paulo: Perspectiva, 2004.

A sociedade de consumo. Trad. de Artur Morão. Lisboa: Edições 70, 2003.

Da sedução. 5. ed. Trad. de Tânia Pellegrini. Campinas, SP: Papirus, 1991.

CANCLINI, Néstor García. Culturas Híbridas: estratégias para entrar e sair da modernidade. 4. ed. Trad. de Heloísa Pezza Cintrão; Ana Regina Lessa. São Paulo: Ed. da USP, 2003.

Consumidores e Cidadãos: conflitos multiculturais da globalização. 4. ed. Rio de Janeiro: Ed. da UFRJ, 1999.

FRANK, Arthur. "For a sociology of the body: an analytical review". In: FEATHERSTONE, Mike et al. (Ed.). The body. Social process and cultural theory. London: Thousand Oaks; New Delhi: Sage Publications, 1996.

FREUD, Sigmund. O mal-estar na civilização. Trad. José Octávio de Aguiar Abreu. Rio de Janeiro: Imago, 1997.

JEUDY, Henri-Pierre. O corpo como objeto de arte. Trad. Tereza Lourenço. São Paulo: Estação Liberdade, 2002.

LE BRETON, David. Adeus ao corpo: Antropologia e Sociedade. Trad. Marina Appenzeller. São Paulo: Papirus, 2003.

LIPOVETSKY, Gilles. Os tempos hipermodernos. Trad. Mário Vilela. São Paulo: Barcarolla, 2004. SANTOS, Jair Ferreira dos. Breve, o pós-humano. Ensaios contemporâneos. 2. ed. Rio de Janeiro: F. Alves, 2003.

YOUNG, Fernanda. A sombra das vossas asas. Rio de Janeiro: Objetiva, 1997.

\section{ARTIGOS, ENTREVISTAS E CRÔNICAS:}

YOUNG, Fernanda. "O biográfico e o ficcional". Entrevista concedida a E.S. Wels em 10 mar. 2004, São Paulo.

. "De cama". Vogue RG, São Paulo, p. 16, abril 2005.

"Me queimei completamente e foi a melhor coisa que fiz na vida". Vogue RG, São

Paulo, p. 72, jun. 2005.

ZAIDAN, Patrícia. Fernanda Young. "A guerreira pós-moderna". Revista Cláudia, São Paulo, p. 31-33, jul.2002.

Recebido em: 15/08/2015 Aceito em: 18/11/2015

Referência eletrônica: WELS, Érica Schlude. A sombra das vossas asas: o corpo como rascunho e projeto de si. Criação \& Crítica, n. 15, p. 175-187, dez. 2015. Disponível em: $<$ http://revistas.usp.br/criacaoecritica>. Acesso em: dd mm aaaa. 